\begin{tabular}{|c|c|}
\hline$A$ & $\begin{array}{c}\text { International Journal of Current Research } \\
\text { and Academic Review }\end{array}$ \\
\hline & $\begin{array}{c}\text { ISSN: 2347-3215 (Online) }, ; \text { Volume } 5 \\
\text { Journal homepage: http://www.ijcrar.com } 7 \text { (July-2017) }\end{array}$ \\
\hline
\end{tabular}

doi: https://doi.org/10.20546/ijcrar.2017.507.004

\title{
A Study on Application of Biomolecules in Healing Concrete Cracks
}

\author{
N. Murugalatha ${ }^{1 *}$, Karan Babbar ${ }^{2}$, Mohini Gupta $^{2}$, Aamir Suhail $^{2}$ and Ayushi ${ }^{2}$ \\ ${ }^{I}$ Department of Agriculture, Quantum Global Campus, Roorkee, India \\ ${ }^{2}$ Department of Civil Engineering, Quantum Global Campus, Roorkee, India
}

*Corresponding author

\begin{tabular}{|c|c|}
\hline Abstract & Article Info \\
\hline $\begin{array}{l}\text { Cracks in concrete are inevitable and are one of the inherent weaknesses of concrete. } \\
\text { Water and other salts seep through these cracks, corrosion initiates, and thus reduce the } \\
\text { life of concrete. So there was a need to develop an inherent biomaterial, a self-repairing } \\
\text { material which can remediate the cracks and fissures in concrete. Bacterial concrete is } \\
\text { a material, which can successfully remediate cracks in concrete. This technique is } \\
\text { highly desirable because the mineral precipitation induced as a result of microbial } \\
\text { activities is pollution free and natural. As the cell wall of bacteria is anionic, metal } \\
\text { accumulation (calcite) on the surface of the wall is substantial, thus the entire cell } \\
\text { becomes crystalline and they eventually plug the pores and cracks in concrete. This } \\
\text { paper discusses the plugging of artificially cracked cement mortar using bacillus spore } \\
\text { former bacteria filling material in artificially made cuts in cement mortar which was } \\
\text { cured in normal tap water. The effect on the compressive strength and stiffness of the } \\
\text { cement mortar cubes due to the mixing of bacteria is also discussed in this paper. It } \\
\text { was found that use of bacteria improves the stiffness and compressive strength of } \\
\text { concrete. Scanning electron microscope (SEM) is used to document the role of bacteria } \\
\text { in microbiologically induced mineral precipitation. Rod like impressions was found on } \\
\text { the face of calcite crystals indicating the presence of bacteria in those places. Energy- } \\
\text { dispersive X-ray (EDX) spectra of the microbial precipitation on the surface of the } \\
\text { crack indicated the abundance of calcium and the precipitation was inferred to be } \\
\text { calcite }\left(\mathrm{CaCO}_{3} \text { ). }\right.\end{array}$ & $\begin{array}{l}\text { Keywords } \\
\text { Concrete cracks, } \\
\text { Healing, } \\
\text { Biomaterial, } \\
\text { Compressive strength }\end{array}$ \\
\hline
\end{tabular}

\section{Introduction}

Concrete is the most commonly used man-made materials on earth. It is an important construction material used extensively in buildings, bridges, roads and dams (Shrinivasa Reddy et al., 2012). Concrete is useful as it is economical (Rajesh K. Verma et al., 2015) and can be easily made from locally available fine and coarse aggregates. Concrete and steel have approximately equal coefficients of thermal expansion. It can be pumped and hence it can be laid in difficult positions also, durable, fire resistant and requires very little maintenance. Though, it has lots of advantages, it also has many disadvantages like (a) Weak in tension (Mayur Shantilal Vekariya and Jayesh Kumar Pitroda, 2013), (b) low durability, (c) low strength to weight ratio, (d) concrete expands and contracts with the change in temperature, (e) fresh concrete shrinks on drying and hardened 
concrete expand on wetting, (f) concrete under sustained loading undergoes creep, $(\mathrm{g})$ resulting in the reduction of prestress in the prestressed concrete construction, (h) synthetic polymers such as Epoxy treatment etc., are currently being used for repair of concrete which are harmful to the environment. Hence, the use of a biological repair technique in concrete is focused. Recently, it was found that microbial mineral precipitation resulting from metabolic activities of favorable microorganisms in concrete improved the overall behavior of concrete (Mayur Shantilal Vekariya and Jayeshkumar Pitroda, 2013).

Cracking is the most common indication of the distress in a concrete structure. It may affect appearance and may lead to lack of durability. Cracking occurs in concrete due to multiple reasons - cracking due to plasticity of concrete, due to hardening of concrete, due to thermal cracking, cracking due to chemical reactions, cracking due to weathering, cracking due to corrosion of reinforcement, etc. Therefore, cracking reduces the performance of structure and require expensive maintenance in terms of repairs (Seshagiri Rao, 2013; Hafsa, 2013). However, cracking in concrete structures is not necessarily a cause for accusing the designer, builder or supplier. What really matters is the type of structures and the nature of cracking, as this process of damage occurs in the early life of building structures and also during lifetime.

The engineer should be aware of the causes, evaluation, techniques and the method of repair. Some of the most commonly used commercial methods for healing cracks are - Concrete Replacement, Mortar Replacement, Grouting, Large Volume Prepacked Convert and Gunitting. Though the above mentioned methods are not cost and time effective, biological methods have been designed to heal the cracks in the building. Microorganisms are found to be effective in self-healing the concrete cracks. Self-healing mechanism in concrete are incorporated to overcome costly manual maintenance and repair. Although micro-cracks do not necessarily result in significant strength loss of concrete, the ingress of water and other reactive chemicals such as chloride and water may pose a threat to the steel reinforcement as these strongly enhance its corrosion rate. Thus for durability reasons and potential repair costs, crack occurrences should be minimized or, alternatively, occurring cracks should ideally be healed directly after formation by an autonomous repair mechanism (Jhonkers and Schlangen, 2013). Before any repair work is taken in hand the cause of damage must be easily identified for which careful investigation is required. Self-healing, of concrete would save a substantial amount of money, as manual inspection and crack repair could be minimized. Thus a reliable self-healing mechanism for concrete would not only result in more durable structures, but would also be beneficial for the global economy (Jhonkers and Schlangen, 2013). One such an alternative repair mechanism is currently being studied, i.e. a novel technique based on the application of bio-mineralization of bacteria in concrete.

The applicability of specifically calcite mineral precipitating bacteria for concrete repair and plugging of pores and cracks in concrete has been recently investigated and studies on the possibility of using specific bacteria as a sustainable and concrete-embedded self-healing agent was studied and results from ongoing studies are discussed. The main objective of the present study is to isolate and identify the spore formers, preparation and characterisation of the strength of bacterial concrete and to check the potential of bacterial concrete in calcite precipitation.

\section{Materials and Methods}

\section{Cement and coarse aggregate}

Portland Pozzolana fly ash based cement is used in the investigation. The cement used has been tested for various properties as per IS: 4031-1988 and found to be confirming to various specifications of IS: 12269-1987. The cement has a specific gravity of 3.48 . The coarse aggregate of $12.5 \mathrm{~mm}$ and down size, having a specific gravity of 3.33 and a fineness modulus of 2.101, tested as per IS: 10262 is used. Natural river sand with specific gravity of 3.20 and confirming to IS: 383 zone IV is used. The sand was tested as per IS: 10262. Locally available portable water confirming to standards specified in IS: $456-2000$ is used. The cube moulds $(150 \times 150 \mathrm{~mm})$ was placed in position on an even surface. All the interior faces and sides were coated with mud oil to prevent the sticking of concrete to the moulds. Table 1 shows the specific gravity of the specimen.

\section{Isolation, identification and characterization of bacteria}

The curd sample collected from the local market was serially diluted and plated on to the nutrient agar medium. Large flat colonies were isolated and purified cultures were stored in a fresh medium at $4^{\circ} \mathrm{C}$ for further studies. The colonies were subjected to gram staining, 
endospore staining and biochemical characterization (Kandler and Weiss, 1986; Sharpe et al., 1979).

\section{Preparation of concrete mix, cubes and samples labeling}

Mix design can be defined as the process of selecting suitable ingredients of concrete and determining their relative proportions with the object of producing concrete of certain minimum strength and durability as economically as possible. In our investigation we have made M 30 grade of concrete. The mix ratio obtained after the mix design as per IS 456: was M30 (1:1.92:2.89). The $\mathrm{pH}$ of the concrete was maintained to be between 7 and 8 . Therefore it gives the basis that bacterial solution will survive and further concreting work proceeded.

Further, we have poured the concrete in the cube Moulds and six different samples were made which are as follows

\section{Conventional concrete of grade M 30 as control}

2. Concrete with $3 \%$ bacterial solution and calcium lactate

3. Concrete with $5 \%$ bacterial solution and calcium lactate

4. Concrete with 3\% bacterial solution and curd (Natural medium of calcium - lactate)

5. Concrete with 5\% bacterial solution and curd (Natural medium of calcium - lactate)

\section{Slump cone test}

The metal plate i.e. base is placed on a smooth surface and the container is filled with bacterial concrete in three layers, whose workability is to be tested. Each layer is temped 25 times with a standard $16 \mathrm{~mm}$ (5/8 in) diameter steel rod, rounded at the end. When the mould is completely filled with bacterial concrete, the top surface is struck off (leveled with moulds top opening) by means of screening and rolling motion of the temping rod.

The moulds firmly held against its base during the entire operation so that it could not move due to the pouring of concrete by means of handles or foot - rests. Immediately after filling is completed and the concrete is levelled, the cone is slowly and carefully lifted vertically, an unsupported bacterial concrete will now slump. The slump is measured by placing the cone just besides the slump concrete and the temping rod is placed over the cone so that it should also come over the area of slumped concrete. The decrease in height of concrete to that of Moulds is noted with scale which is found to be $110 \mathrm{~mm}$ for conventional concrete and $50 \mathrm{~mm}$ for bacterial concrete. Figure shows the performance of slump cone test.

\section{Preparation of microbial cement mortar}

The mortar was prepared using sand: cement ratio $3: 1$ by weight. One inch cubic moulds were prepared. Sand and cement were thoroughly mixed, adding along with grown culture, at a W/C ratio of 0.46 correspondences to OD AT $600 \mathrm{~nm}$. The fresh mortar pastes were cast into the mold and compacted on a vibration machine then cured in humidity chamber with relative humidity $100 \%$ for 24 h. After de-molding the control specimens were cured under tap water and the specimens with bacteria were cured under tap water and the specimens with bacteria were cured under solution of $20 \mathrm{~g} / \mathrm{l}$ urea and $25 \mathrm{Mm}$ $\mathrm{CaCl} 2$ at room temperature until the times of testing at the intervals of 3, 7 and 28 days.

\section{Compressive strength test}

The concrete cubes were removed from the tank after their respective days of curing. The cubes were allowed to dry under the laboratory condition.

Once the cubes were completely dried, they were placed under the compressive testing machine with an intention to get the compressive strength of concrete. Readings of each bacterial concrete sample were taken each time after curing interval of 3 days, 7 days and 28 days.

\section{Water absorption}

Water absorption measurements were done by weighing the saturated specimens (W1) and dried specimens in oven at $80^{\circ} \mathrm{C}$ for $24 \mathrm{~h}$ (W2) at curing times of 28 days. The water absorption is calculated from following equation:

Water absorption, \% $=[(\mathrm{W} 2-\mathrm{W} 1) / \mathrm{W} 1] \times 100$.

\section{Scanning Electron Microscopy (SEM) analysis for self-healing property}

At the end of 28 days of curing the crack is made on the cubes. Again it is allowed to cure for 28 days. Concrete cubes are analyzed under SEM after 28 days of curing. 


\section{Results and Discussion}

\section{Isolation and characterisation of biomolecules}

Bacillus spore former were isolated from natural medium i.e. curd sample by serial dilution technique. Large flat irregular colonies were isolated and the purified cultures were maintained at $4^{\circ} \mathrm{C}$ in nutrient broth for further studies. Seshagiri et al., (2013) in their work stated that the concrete is a highly alkaline building material, so bacteria used as self-healing agent should be able to survive in this high alkaline environment for long durations and should also be able to form spores. Jonkers and Schlangen, (2009) used bacterial species B. cohnii, $B$. halodurans and B. pseudofirmus for healing the cracks and explained application of self-healing concrete i.e. concrete that is able to repair, seal or plug newly formed cracks autogenously, will not only result in more durable structures but will also save a significant amount of money as labor intensive check and repairs can be minimized.

\section{Bio chemical characterization of isolate}

The isolates were found to be obligate aerobes, grampositive, endospore positive (Plate 1), indole negative, Methyl red positive, Voges Proskauer positive, Citrate Utilization positive, Starch hydrolysis positive, Urea hydrolysis negative, Gelatin hydrolysis positive, Nitrate reduction negative, $\mathrm{H}_{2} \mathrm{~S}$ production positive, Catalase positive, Oxidase positive, Glucose fermentation positive, Adonitol fermentation positive, Lactose fermentation positive (Table 2).

\section{Strength characteristic of concrete}

Portland Pozolana fly ash cement, coarse aggregate of $12.5 \mathrm{~mm}$ size having a specific gravity of 3.33 and fineness modulus of 2.1, fine aggregate with specific gravity of 3.2 is mixed with water and concrete mix is prepared. The cube moulds of size $150 \times 150 \mathrm{~mm}$ were coated with mud oil to prevent sticking of mix on interior surfaces.

The concrete slump test is an empirical test that measures workability of fresh concrete and indicates the behaviour of a compacted concrete cone under the action of gravitational forces. The value of slump test was found to be $110 \mathrm{~mm}$ for conventional concrete and $50 \mathrm{~mm}$ for bacterial concrete.

The block was made using calcium lactate and curd with the mixture of micro-organism and their compressive strength was checked at 3, 7 and 28 days respectively. The compressive strength of 3\% bacteria and 5\% curd was $14.2,26.1$ and $38.92 \mathrm{MPa}$ at 3,7 and 28 days respectively. The compressive strength of $5 \%$ bacteria and $10 \%$ curd was $12.6,21.4$ and $33.62 \mathrm{MPa}$ at 3, 7 and 28 days respectively.

The compressive strength of $3 \%$ bacteria and $5 \%$ calcium lactate was 16.96, 25.1 and $39.92 \mathrm{MPa}$ at 3, 7 and 28 days respectively. The compressive strength of $5 \%$ bacteria and $10 \%$ calcium lactate was $13.68,21.2$ and $34.1 \mathrm{MPa}$ at 3, 7 and 28 days respectively (Table 3 and Fig.1).

Fig.1 Comparative analysis of compressive strengths of concrete mixture

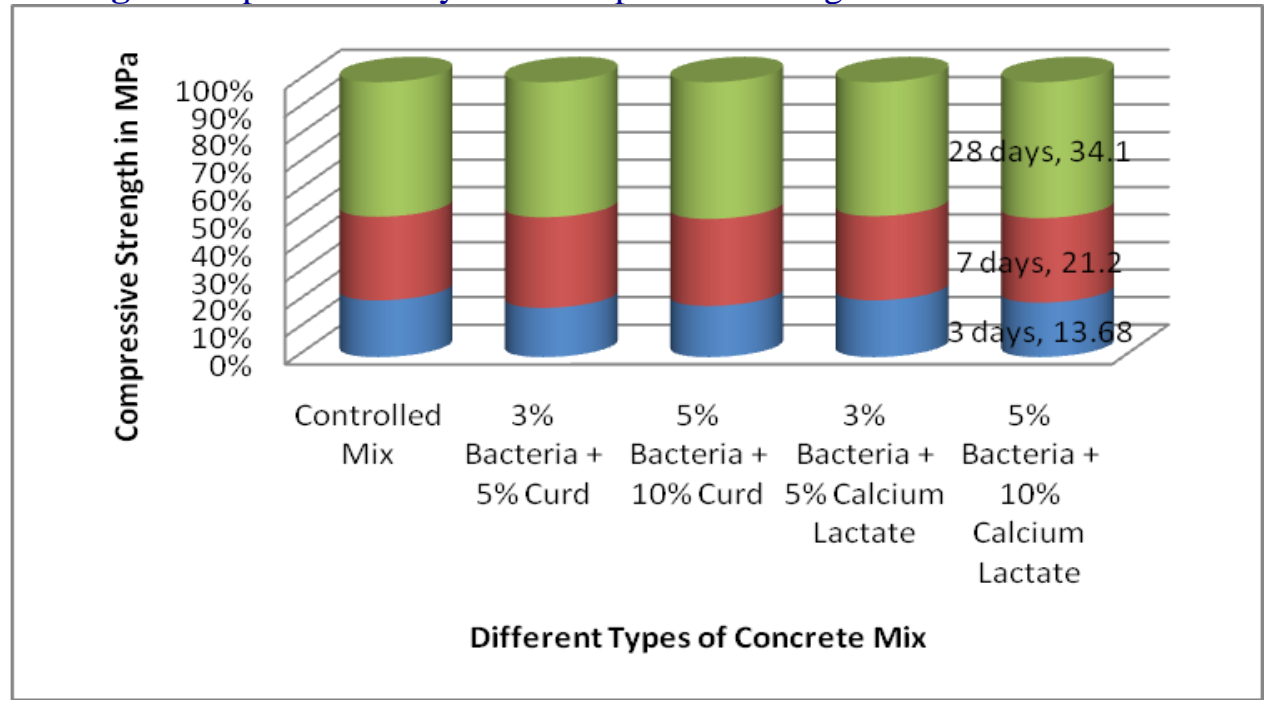


Plate.1 Isolation of the Endospore former and Gram reaction

\section{a. Quadrant streak}

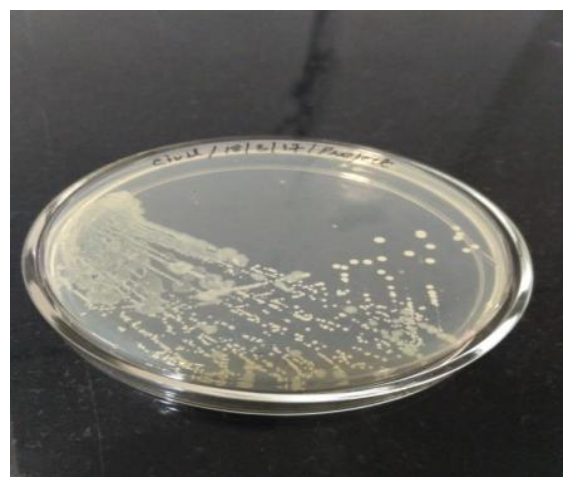

\section{b. Endospore staining of the isolate}

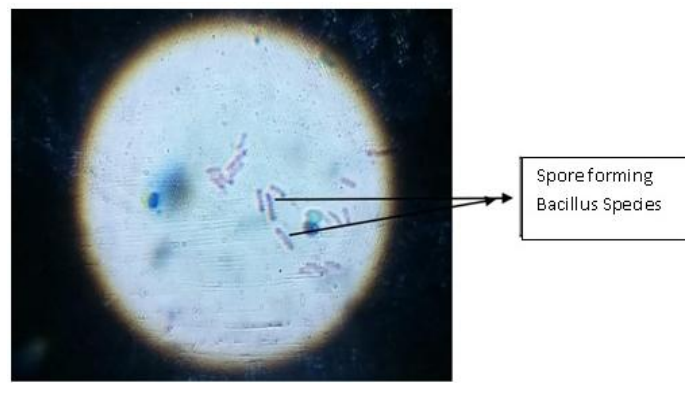

Plate.2 SEM Image of Normal Concrete

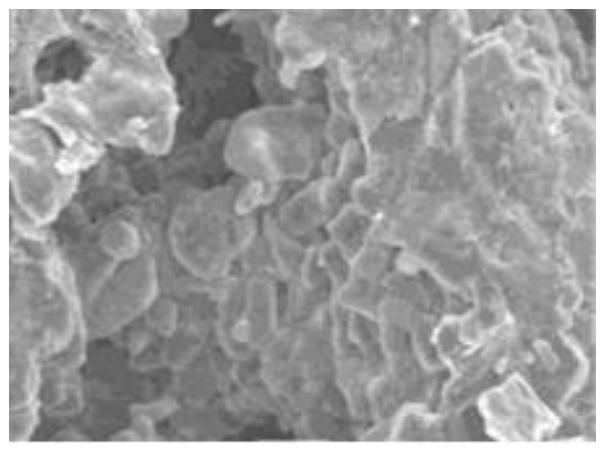

Plate.3 SEM Image of Bacillus spore formers

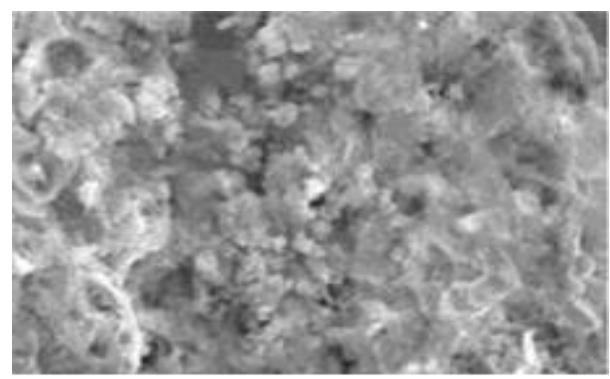


Plate.4 Crack in normal concrete after 28 days of curing

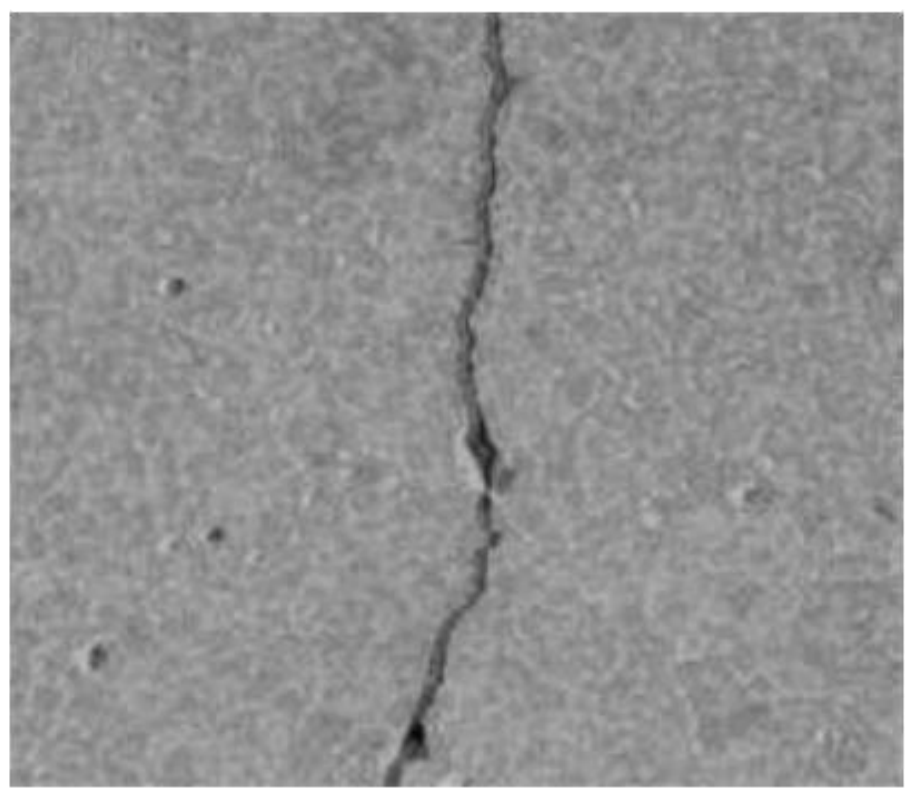

Plate.5 Reduction of thickness of crack size after healing

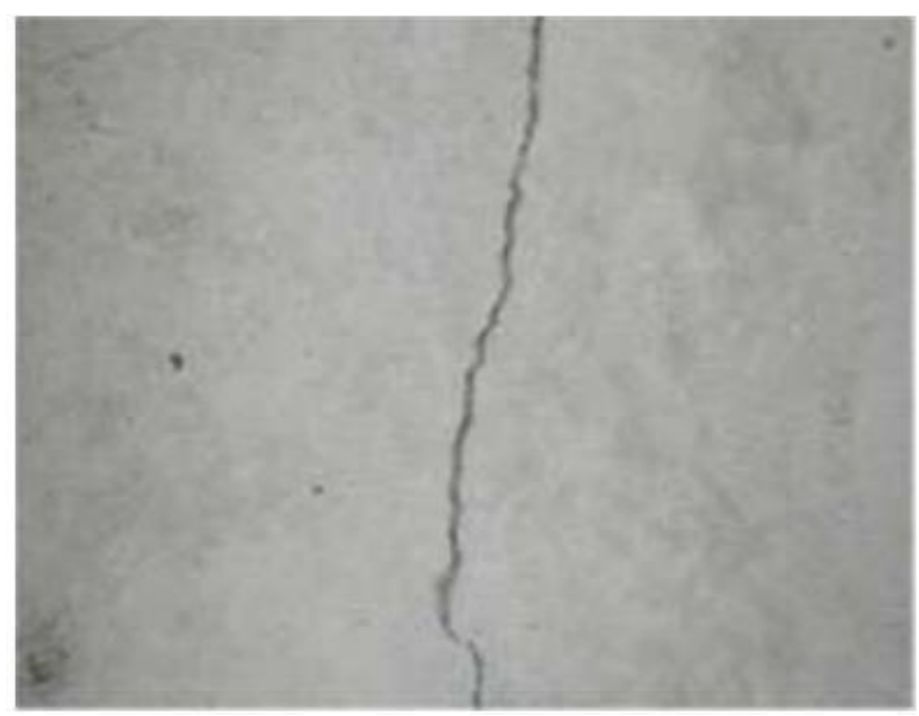

Table.1 Specific gravity of the component

\begin{tabular}{|l|c|}
\hline Component & Specific gravity \\
\hline Cement & 3.48 \\
\hline Coarse Aggregate & 3.33 \\
\hline Fine Aggregate & 3.2 \\
\hline
\end{tabular}


Table.2 Biochemical characterization of the isolate

\begin{tabular}{|l|c|}
\hline Biochemical Test & Observation \\
\hline Gram's staning & + \\
\hline Endospore Staining & + \\
\hline Indole Test & + \\
\hline Methyl red Test & + \\
\hline Voges Proskauer Test & + \\
\hline Starch Hydrolysis Test & + \\
\hline Urea Hydrolysis Test & + \\
\hline Gelatin Hydrolysis Test & + \\
\hline Nitrtae Reduction Test & + \\
\hline H2S Test & + \\
\hline Catalase Test & + \\
\hline Oxidase Test & + \\
\hline Glucose Fermentation Test & + \\
\hline Adonitol Fermentation Test & + \\
\hline
\end{tabular}

Table.3 Compressive strength of different concrete mixes

\begin{tabular}{|c|c|c|c|}
\hline MIX ID & COMI & SIVE S & NGTH \\
\hline No. of days & $\beta$ days & 7 days & 28 days \\
\hline Controlled Mix & 16.73 & 24.62 & $\beta 9.62$ \\
\hline $3 \%$ Bacteria $+5 \%$ Curd & 14.2 & 26.1 & $\beta 8.92$ \\
\hline $5 \%$ Bacteria $+10 \%$ Curd & 12.6 & 21.4 & 33.62 \\
\hline $3 \%$ Bacteria $+5 \%$ Calcium Lactate & 16.96 & 25.1 & $\beta 9.92$ \\
\hline $5 \%$ Bacteria $+10 \%$ Calcium Lactate & 13.68 & 21.2 & 34.1 \\
\hline
\end{tabular}


Table.4 Water absorption test of different types of concrete mix

\begin{tabular}{|l|c|}
\hline Type of Concrete Mix & $\begin{array}{l}\text { Average water } \\
\text { absorption after 28 days }\end{array}$ \\
\hline Controlled Mix & 4.9 \\
\hline Using Isolate (with calcium lactate) & 2.35 \\
\hline Using Isolate (with curd) & 2.6 \\
\hline
\end{tabular}

The compressive strength values of concrete using 3\% bacteria and 5\% curd was found to be increased when compared with control mix. It was also observed that pores in concrete are partially filled up by material growth with the addition of bacteria and curd. Reduction in pores will obviously increase the density of the material and strength. As the pores in concrete are filled by bacteria, a chance of development of cracks reduces considerably. Hence, bacteria along with calcium lactate or curd can be used as a self-healing agent. The increase in strength may be due to reduction I pores of concrete with the incorporation of bacteria. It is also observed that the calcium lactate and curd gives similar results. This is due to the reason that curd is the natural medium of calcium lactate.

Several research works have determined that compressive strength increases $28 \mathrm{~d}$ with 9 to $25 \%$ when mixing the cells into mortor or concrete (Gosh et al., 2009; Achal et al., 2012; Basaran, 2013). Few authors have mentioned that bases on cell concentration and the nature of the isolate showed both positive and negative effects (Park et al., 2010; Gosh et al., 2005).

The bacteria has the capability to transform soluble organic nutrients into soluble inorganic calcite crystals, which seals the crack. The bacteria and nutrients incorporated into the concrete should not disturb the integrity of cement sand material pore- diameter and should not affect the properties of concrete (Soundarya and Niramalkumar, 2014).

\section{Water absorption test}

Table 4 shows that water absorption of normal concrete is higher than concrete made up of isolate (with curd and calcium lactate). It was observed that the water absorption was higher in isolate with curd when compared to isolate with lactate.
Scanning Electron Microscopy (SEM) analysis for self-healing property

The self-healing property was observed in cubes after 14 days of creating crack in curd cubes. The isolates treated cubes with curd and calcium lactate were found to have lesser voids than normal concrete and they are comparatively closely packed (Plate 2 and 3 ). Plate 4 and Plate 5 shows the comparisons of healing mechanism. It was observed that the thickness of the cracks was decreased after 14 days in the cube treated with spore formers.

Based on our experimental investigations the following conclusions are drawn

1. 1.Self-healing concrete is a product that will biologically produce limestone to heal cracks that appear on the surface of concrete structures.

2. 2.Cementations by this method is very easy and convenient for usage because of its eco-friendly nature.

3. 3.The addition of bacillus spore former bacteria increases the compressive strength of concrete.

4. 4.There were no considerable differences found when the compressive strength of concrete using calcium lactate and bacteria was compared with the compressive strength of concrete using curd and bacteria. Thus, the use of curd in place of calcium lactate gave similar results as curd is a natural medium of calcium lactate.

5. 5.Bacterial concrete has improved microstructure and permeable properties than controlled concrete. 
6. 6.Our study showed that bacterial concrete has better acid resistance in aggressive environment.

\section{References}

Achal, V., Mukherjee, A., Goyal, S. and Reddy, M.S. 2012. Corrosion prevention of reinforced concrete with microbial calcite precipitation. ACI Mater. J.109 (2): 157-163.

Basaran, J.Z. 2013. Biomineralization in cement based materials: inoculation of vegetative cells. $\mathrm{PhD}$ in civil engineering. The University of Texas at Austin.

Ghosh, S., Biswas, M., Chattopadhyay, B.D. and Mandal, S. 2009. Microbial activity on the microstructure of bacteria modified mortar. Cem. Concr. Comp., 31(2): 93-98.

Ghosh, P., Mandal, S., Chattopadhyay, B.D. and Pal, S. 2005. Use of microganism to improve the strength of cement mortar. Cem. Concr. Res., 35(10): 19801983.

Jhonkers, H.M., and Schlangen, E.2009. Delft University of Technology, Self-healing of Cracked Concrete: A bacterial approach. Restoration of Buildings and Monuments. 15(4):255-266.

Kandler, O. and Weiss, N. 1986. Genus Lactobacillus Beijerinck 1901, 212AL. In: Bergey's Manual of Systematic Bacteriology. 2: 1209-1234.

Mayur Shantilal Vekariya, Jayeshkumar Pitroda, B.V.M.2013. Engineering College, Vallabh Vidhyanagar- Gujarat, Bacterial Concrete: New Era for Construction Industry. International Jouranal of Engineering Trends and Technology.
Park, Y.M., Park, W.Y., Chun, W.J. and Kim, S.Y. 2010. Calcite-forming bacteria for compressive strength improvement in mortar. J. Microbiol. Biotechnol. 20(4): 782-788.

Rajesh Verma, K., Leena Chaurasia, Vishakha Bisht, Msnish Thakur. 2015. Central Building Research Institute, "Bio-Mineralization and Bacterial Carbonate Precipitation in Mortar and Concrete." Bioscience and Bioengineering, Pp. 5-11.

Seshagiri Rao, M.V., Srinivasa Reddy, V., Hafsa, M., Veena, P. and Anusha P.2013. College of Engineering Hyderabad, "Bioengineered Concrete- A Sustainable Self-Healing Construction Material." Research Journal of Engineerng Sciences.

Sharpe, M.E., T.F. Fryer and D.G. Smith. 1979. Identification of Lactic Acid Bacteria. In: Identification Methods for Microbiologists, Gibbs, E.M. and F.A. Skinner (Eds.). Academic Press, London. pp: 233-259.

Soundharya, S. and Nirmalkumar, K. 2014. Study on the Effect of Calcite-Precipitating Bacteria on SelfHealing Mechanism of Concrete (Review Paper). International Journal of Engineering Research \& Management Technology. 1(4):202-208

Srinivasa Reddy, V., Achyutha Satya, K., Seshagiri Rao, M.V., Azmatunnisa, M. 2012. Centre for Environment, Hyderabad, "A Biological Approach To Enhance Strength and Durability in Concrete Structures. International Journal of Advances in Engineering \& Technology.

\section{How to cite this article:}

Murugalatha, N., Karan Babbar, Mohini Gupta, Aamir Suhail and Ayushi. 2017. A Study on Application of Biomolecules in Healing Concrete Cracks. Int.J.Curr.Res.Aca.Rev. 5(7), 19-27.

doi: https://doi.org/10.20546/ijcrar.2017.507.004 